\title{
Reversal of Digoxin Toxicity with Specific Antibodies
}

\author{
Donald H. Schmidt and Vincent P. Butler, Jr. \\ From the Department of Medicine, Columbia University College of Physicians \\ and Surgeons, New York 10032
}

A в S T R A C T To determine whether digoxin-specific antibodies can reverse established digoxin toxicity in the dog, digoxin intoxication was produced by the intramuscular administration of digoxin, $0.09 \mathrm{mg} / \mathrm{kg}$, on each of 3 consecutive days. All animals developed toxic arrhythmias (atrioventricular block, ventricular premature contractions and/or ventricular tachycardia). In control animals not receiving antidigoxin antibodies, the arrhythmias persisted throughout a $6 \mathrm{hr}$ study period. Seven of the nine control dogs were dead within $24 \mathrm{hr}$ and one moribund animal was sacrificed at that time; the last animal died within $48 \mathrm{hr}$.

In contrast, in six of eight dogs given digoxinspecific antibodies in canine plasma and/or rabbit serum, the arrhythmias reverted to a sinus mechanism within 30-90 min after the start of the infusion. At the end of a $6 \mathrm{hr}$ period of study, these six dogs were in normal sinus rhythm and all eight were alive and in normal sinus rhythm at the end of $72 \mathrm{hr}$. This study provides evidence that digoxin-specific antibodies can reverse severe established digoxin toxicity in the dog.

\section{INTRODUCTION}

Digitalis intoxication is a serious and frequently encountered clinical condition. Since no specific antagonist of digitalis has yet been described, present-day therapy is directed principally at the symptomatic management of the clinical manifestations of digitalis toxicity (2) rather than at its cause. To provide a more direct approach, the present study was designed to determine whether antibodies which specifically bind cardiac glycosides can reverse established digitalis toxicity. The feasibility of this approach was suggested

This work was presented in part at the General Session of the Annual Meeting of the American Society for Clinical Investigation, Atlantic City, N. J., 5 May 1969 (1).

Dr. Schmidt carried out this investigation as a Clinical Science Fellow of the New York Heart Association. Dr. Butler is the recipient of a U. S. Public Health Service Research Career Development Award 1-K04-HE 11,315.

Received for publication 15 January 1971. by earlier studies which demonstrated that rabbits immunized wich synthetic digoxin-protein conjugates form digoxin-binding antibodies (3). These antidigoxin antibodies protect rabbits from the adverse effects of an otherwise lethal dose of digoxin (4). Watson and Butler have also shown that antibodies specific for digoxin can remove intracellular digoxin from renal cortical slices of rats and from human erythrocytes, and are capable of reversing the effects of digoxin on cellular potassium transport (5).

This communication presents evidence that digoxinbinding antibodies are capable of reversing the toxic effects of excessive digoxin in the nonimmunized dog. The potential value of these antibodies in the clinical treatment of life-threatening human digoxin intoxication is discussed.

\section{METHODS}

Preparation of antigens. Digoxin ${ }^{1}$ was conjugated to human serum albumin ${ }^{2}$ (HSA) ${ }^{3}$ or to bovine serum albumin $(\mathrm{BSA})^{3}$ by the periodate oxidation method $(3,6)$ as previously described (7).

Immunization. White New Zealand rabbits were immunized with HSA-digoxin (HSA-Dig) or with BSA-digoxin (BSA-Dig) in complete Freund's adjuvant mixture as described in detail elsewhere (7). Other rabbits were immunized in a similar manner with purin-6-oyl-HSA (PurHSA) (8) or with human $\gamma$-globulin (HGG). ${ }^{4}$

Mongrel dogs weighing from 10 to $20 \mathrm{~kg}$, were immunized by the intramuscular injection of $1 \mathrm{ml}$ of HSA-Dig in complete Freund's adjuvant mixture, once weekly for $4 \mathrm{wk}$, followed by monthly intramuscular booster injections.

Collection of antisera or plasma. Serum was obtained from the rabbits by cardiac puncture or via an ear vein. Some of the bleedings from individual rabbits were pooled. Thimerosal $^{5}$ in a final concentration of $1: 10,000$ was added

\footnotetext{
${ }^{1}$ Courtesy of Dr. Stanley T. Bloomfield, Burroughs Wellcome \& Co. Inc., Tuckahoe, N. Y.

${ }^{2}$ Fraction $\mathrm{V}$ powder, Pentex Inc., Kankakee, Ill.

${ }^{3}$ Abbreviations used in this paper: BSA, bovine serum albumin; BSA-Dig, BSA-digoxin; HGG, human gammaglobulin; HSA, serum albumin; HSA-Dig, HSA-digoxin ; Pur-HSA, purin-6-oyl-HSA.

${ }^{4}$ Fraction II, supplied through the generosity of the American Red Cross by E. R. Squibb \& Sons, New York.

${ }^{5}$ Merthiolate, Eli Lilly \& Co., Indianapolis, Ind.
} 
as a preservative and the sera were stored at $4^{\circ} \mathrm{C}$ until used.

Plasma was obtained from dogs 5-7 days after booster injections by plasmapheresis using the following technique: The dogs were anesthetized by the intravenous administration of sodium thiamylal ${ }^{6}$ ( $5 \%$ solution in isotonic $\mathrm{NaCl} ; 0.2$ $\mathrm{ml} / \mathrm{lb}$ ). Blood was collected in a $250 \mathrm{ml}$ plastic bag containing a citrate anticoagulant solution " through a Teflon catheter ${ }^{8}$ placed in the femoral artery via a cutaneous incision. The blood was then centrifuged at $1000 \mathrm{rpm}$ at $4^{\circ} \mathrm{C}$ for $20 \mathrm{~min}^{\circ}$ or at $5000 \mathrm{rpm}$ at $4^{\circ} \mathrm{C}$ for $3-5 \mathrm{~min}^{10}$ The plasma was then extruded ${ }^{11}$ into a $150 \mathrm{ml}$ plastic bag, ${ }^{12}$ and then stored at $4^{\circ} \mathrm{C}$ until used. No preservative was added. The packed cells were reinfused into the dog through a Teflon catheter ${ }^{8}$ in the vein of the foreleg. The removal of blood, separation of plasma, and readministration of cells were repeated for a total of 3 times so that approximately $450 \mathrm{ml}$ of plasma was obtained per bleeding.

Determination of antibody concentration and digoxinbinding capacity. The presence of digoxin-binding antibodies was determined by the dextran-coated charcoal method $(9,10)$

Titers, which are functions of both antibody affinity and concentration, are expressed as the dilutions of antiserum or plasma, $1 \mathrm{ml}$ of which is capable of binding $50 \%$ of a constant amount of digoxin ${ }^{8} \mathrm{H}(32 \mathrm{~m} \mu \mathrm{g})$. The binding of digoxin ${ }^{-3} \mathrm{H}$ was determined at dilutions capable of binding more than, and less than $50 \%$ of the added digoxin. The dilution capable of binding $50 \%$ was then estimated by extrapolation and expressed as the "digoxin-binding antibody titer."

The total theoretical digoxin-binding capacity of antiserum or plasma administered to dogs 10 through 17 (Table II) was calculated by multiplying the titer by $16 \mathrm{~m} \mu \mathrm{g}$ (to obtain the theoretical digoxin-binding capacity of $1 \mathrm{ml}$ of undiluted serum or plasma), and then multiplying by the total vo'ume (in milliliters) infused.

The presence of antibodies to the protein antigens used in this study was determined by the bis-diazotized benzidine hemagglutination method, using human group " $\mathrm{A}$ " erythrocytes coated with HSA-Dig, BSA-Dig, Pur-HSA, or with HGG as previously described $(4,11)$. Titers were recorded as the highest dilutions of sera which yielded an agglutination pattern of two-plus or greater (11).

Administration of digoxin for the induction of digitalis toxicity. Unanesthetized mongrel dogs weighing between 8 and $18 \mathrm{~kg}$ were given $0.09 \mathrm{mg}$ digoxin per $\mathrm{kg}$ (digoxin 0.25 $\mathrm{mg} / \mathrm{ml}$ in a $40 \%$ propylene glycol: $10 \%$ ethanol solution ${ }^{1}$ ) intramuscularly once daily for 3 consecutive days. The animals were weighed before each dose of digoxin and then placed upright in a sling. With a oscilloscopic recorder ${ }^{13}$ and

\footnotetext{
${ }^{6}$ Suritol, Parke Davis \& Co., Detroit, Mich.

7 JA-4 Blood Pack Hemo System, Fenwal Laboratories, Inc., Division of Travenol Inc., Morton Grove, IIl.

${ }^{8}$ Longdwel Catheter Needle, Becton-Dickinson \& Co., Rutherford, N. J.

${ }^{\bullet}$ Model PR-2 refrigerated centrifuge, International Equipment Company, Boston, Mass.

${ }^{10}$ Sorvall RC-3 superspeed centrifuge, Ivan Sorvall Inc., Norwalk, Conn.

11 Plasma Extractor, Fenwal Laboratories Inc., Division of Travenol Inc., Morton Grove, Ill.

${ }_{12}$ TA-3 Transfer Pack, Fenwal Laboratories Inc., Division of Travenol Inc., Morton Grove, Ill.

${ }^{13}$ Model PR-7, Electronics for Medicine Inc., White Plains, N. Y.
}

needle electrodes, a six lead electrocardiogram was recorded on photographic paper using paper speeds of $25 \mathrm{~mm} / \mathrm{sec}$ and an additional recording was obtained at a paper speed of 75 $\mathrm{mm} / \mathrm{sec}$ for the evaluation of rhythm. Arrhythmias appeared 1-3 hr after the 3rd dose of digoxin. When an arrhythmia had been present for $30.60 \mathrm{~min}$, a $6 \mathrm{hr}$ study period was begun. During this $6 \mathrm{hr}$ study period, the animal was kept suspended in the sling and rhythm strips were recorded every $15 \mathrm{~min}$. All electrocardiograms were analyzed for heart rate, rhythm, P-R interval, and QRS duration.

Administration of serum or plasma. With the dog suspended in the standing position in the sling, varying amounts of canine plasma or rabbit serum were infused through a Nylon filter ${ }^{14}$ and a Teflon catheter $^{8}$ over a 15-30 min period, starting 1-2 $\mathrm{hr}$ after the onset of digoxin toxicity. Some animals were given additional infusions at later times as indicated in Fig. 2.

Determination of serum or plasma potassium concentration. The concentration of potassium in the canine plasma or rabbit serum infused was determined by means of a flame photometer. $^{15}$

\section{RESULTS}

Digoxin toxicity. Electrocardiographic and gastrointestinal manifestations of digoxin intoxication appeared in all 17 dogs receiving the dose of digoxin employed in this study $(0.09 \mathrm{mg} / \mathrm{kg}$ intramuscularly, once daily for 3 consecutive days). No toxic manifestations were noted after the first dose of digoxin, but all animals weighed less before the second and third injections of digoxin. Following the 2nd dose, transitory vomiting and diarrhea were noted in some animals but, prior to the third dose of digoxin, all were in normal sinus rhythm. Within 1 to $3 \mathrm{hr}$ after the third dose, each dog had developed a sustained arrhythmia. These arrhythmias included: Atrioventricular dissociation with ectopic ventricular beats; atrioventricular dissociation with a junctional rhythm; various forms of atrioventricular block; slow idioventricular rhythm with no evidence of atrial activity; and ventricular tachycardia (Fig. 1). The development of one of these arrhythmias was the criterion used for the presence of digoxin toxicity but, in addition to these arrhythmias, the animals displayed anorexia, protracted vomiting, diarrhea, weakness, and apathy.

Digoxin toxicity in untreated dogs and dogs receiving control serum or plasma. The course of digoxin toxicity in nine dogs, none of whom received digoxin-specific antibodies is summarized in Table I and is depicted in Fig. 2. All nine dogs exhibited arrhythmias which persisted throughout the $6 \mathrm{hr}$ study period. Normal sinus rhythm was not observed at any time (Fig. 2). Seven of these dogs were dead within $24 \mathrm{hr}$ and one moribund animal was sacrificed at this time. The last dog died within $48 \mathrm{hr}$.

\footnotetext{
${ }^{14}$ Pliapak, Abbott Laboratories, North Chicago, Ill.

${ }^{15}$ Model 143, Instrumentation Laboratory Inc., Boston, Mass.
} 


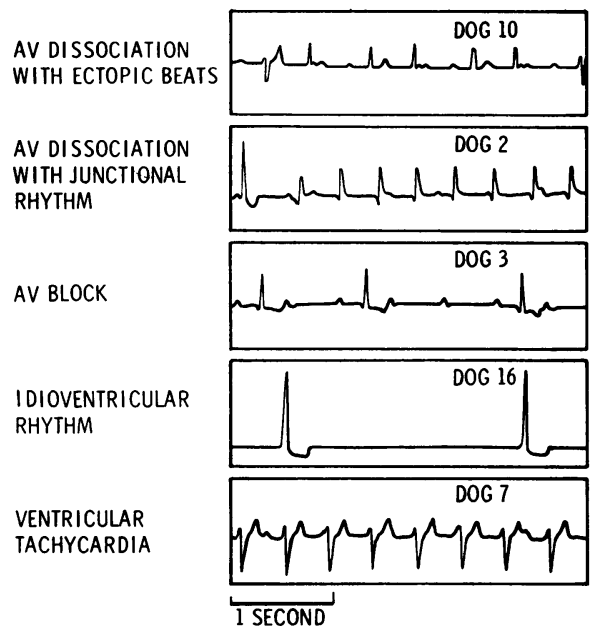

Figure 1 Digitalis toxic rhythms. Electrocardiographic tracings from dogs that received the toxic amount of digoxin. The tracings were all taken at the beginning of the $6 \mathrm{hr}$ study period. (AV, atrioventricular.)

The arrhythmias and eventual lethal outcome in dogs 6 and 7 were not affected by the administration of normal canine plasma in two $130 \mathrm{ml}$ portions (Fig. 2). Dogs 8 and 9 each received, without apparent effect, $400 \mathrm{ml}$ of rabbit serum containing antibodies to antigens unrelated to digoxin $1 \mathrm{hr}$ after the onset of their arrhythmias (Fig. 2). Dog 8 received serum containing antibodies to Pur-HSA and $\operatorname{dog} 9$ received serum con- taining antibodies specific for HGG. The rabbit sera contained antibodies to the corresponding antigens, but neither the canine plasma nor the rabbit sera contained digoxin-binding antibodies (Table II).

Effect of digoxin-specific antibodics on the course of digoxin toxicity. After digoxin-induced arrhythmias had been allowed to persist for $1 \mathrm{hr}$ in eight animals (dogs 10 through 17), serum or plasma from animals immunized with digoxin-protein conjugates was administered intravenously in the amounts indicated in Table II. All such serum or plasma administered contained digoxin-binding antibodies (Table II). Potassium concentrations did not differ significantly from the potassium concentrations of control serum or plasma (Table II) nor from the normal potassium concentrations of rabbit serum (12). The reported potassium concentrations for heparinized canine plasma (13) are higher than those encountered in the present study (Table II), but these lower concentrations may reflect dilution by citrated anticoagulant solution. In no instance did the total volume of antidigoxin serum or plasma administered exceed the maximum volume of serum or plasma $(400 \mathrm{ml})$ given to control animals (Table II).

The effect of these digoxin-specific antibodies on the arrhythmias in these animals is outlined in Table III and graphically represented in Fig. 2. Dog 10 had atrioventricular dissociation which reverted to normal sinus rhythm within $1 \mathrm{hr}$ after the administration of

TABLE I

Summary of Arrhythmias Observed and Infusions Given in Control Dogs

\begin{tabular}{|c|c|c|c|c|c|}
\hline \multirow{2}{*}{$\begin{array}{l}\text { Dog } \\
\text { No. }\end{array}$} & \multirow[b]{2}{*}{ Infusion } & \multirow{2}{*}{$\begin{array}{l}\text { Rhythm } \\
\text { before } \\
\text { 3rd dose } \\
\text { of digoxin }\end{array}$} & \multicolumn{3}{|c|}{ Rhythm* at various times during $6 \mathrm{hr}$ study period } \\
\hline & & & 0 time $\ddagger$ & $3 \mathrm{hr}$ & $6 \mathrm{hr}$ \\
\hline 1 & None given & NSR & VPC's & VPC's & VPC's \\
\hline 2 & None given & NSR & Ventricular tachycardia & Ventricular tachycardia & Ventricular tachycardia \\
\hline 3 & None given & NSR & Sinus arrest; VPC's & VPC's & Ventricular tachycardia \\
\hline 4 & None given & NSR & Complete AV block & Complete AV block & $\begin{array}{l}\text { Idioventricular rhythm; } \\
\text { no atrial activity }\end{array}$ \\
\hline 5 & None given & NSR & Junctional rhythm & Junctional rhythm & Junctional rhythm \\
\hline 6 & $\begin{array}{l}\text { Normal canine } \\
\text { plasma }\end{array}$ & NSR & $\begin{array}{l}\text { Variable AV block; } \\
\text { junctional rhythm }\end{array}$ & $\begin{array}{l}\text { Idioventricular rhythm; } \\
\text { no atrial activity }\end{array}$ & $\begin{array}{l}\text { Idioventricular rhythm } \\
\text { no atrial activity }\end{array}$ \\
\hline 7 & $\begin{array}{l}\text { Normal canine } \\
\text { plasma }\end{array}$ & NSR & VPC's & Ventricular tachycardia & Ventricular tachycardia \\
\hline 8 & $\begin{array}{l}\text { Rabbit anti-Pur- } \\
\text { HSA serum }\end{array}$ & NSR & $3: 1$ AV block & $\begin{array}{l}\text { Junctional rhythm; } \\
\text { VPC's; no atrial } \\
\text { activity }\end{array}$ & Junctional rhythm \\
\hline 9 & $\begin{array}{l}\text { Rabbit anti-HGG } \\
\text { serum }\end{array}$ & NSR & Ventricular tachycardia & $\begin{array}{l}\text { Junctional rhythm; no } \\
\text { atrial activity }\end{array}$ & $\begin{array}{l}\text { Junctional rhythm; no } \\
\text { atrial activity }\end{array}$ \\
\hline
\end{tabular}

VPC's, frequent ventricular premature contractions with occasional short periods of ventricular tachycardia; NSR, normal sinus rhythm; AV, atrioventricular.

* Refers to predominant arrhythmia.

$\ddagger$ Start of $6 \mathrm{hr}$ study period at onset of arrhythmia, 1-3 hr after third dose of digoxin. 
$130 \mathrm{ml}$ of antidigoxin serum. The frequent premature ventricular contractions with occasional brief periods of ventricular tachycardia disappeared in dog 11 within 30 min after the infusion of antidigoxin antibodies, but a slightly prolonged PR interval $(160 \mathrm{msec}$ as compared to a control of $120 \mathrm{msec}$ ) persisted throughout the $6 \mathrm{hr}$ study period. The administration of additional antibody had no effect on the PR interval. The arrhythmia noted in $\log 12$ (3:1 atrioventricular block) responded promptly to a single large dose of antibody with reversion to normal sinus rhythm. However, transient periods of variable atrioventricular block and rentricular tachycardia recurred; this arrhythmia disappeared after the administration of additional antibody. The ventricular tachycardia in $\log 13$ required two infusions of antibody before normal sinus rhythm was restored. In $\operatorname{dog} 14$, complete atrioventricular block. and in $\log 15,2: 1$ atrioventricular block disappeared after the administration of antibody but later recurred: both of these arrhythmias subsided spontaneously in the 6 hr study period without the administration of additional antibody. Dog 16 had an idioventricular rhythm with no atrial activity and $\log 17$ initially had rentricular tachycardia. These ventricular arrhythmias were replaced within $1-1 \frac{1}{2}$ hours after the initial administration of antiboly by atrial tachycardia with variable block and a ventricular response of 80-100. Dog 16 reverted to normal sinus rhythm within $72 \mathrm{hr}$ and $\log 17$ within $48 \mathrm{hr}$.

In contrast to the nine control $\log s$, all eight animals treated with antidigoxin antibodies were free of gastrointestinal and other clinical manifestations of digitalis intoxication by the end of the study period and all were alive at the end of a $72 \mathrm{hr}$ observation period.

The results in digoxin-intoxicated dogs given antidigoxin antibodies are compared with the end results of digoxin intoxication in control animals in Table IV. Of the nine control animals, none were in normal sinus rhythm at the end of the $6 \mathrm{hr}$ study period and all were dead within $48 \mathrm{hr}$ after the last injection of digoxin. In contrast. six of the eight dogs given digoxinspecific antibodies were in normal sinus rhythm at the end of $6 \mathrm{hr}$, and all were alive and in normal sinus rhythm at the end of 72 hr.

\section{DISCUSSION}

This study presents evidence that $0.09 \mathrm{mg} / \mathrm{kg}$ digoxin administered intramuscularly on each of 3 consecutive days uniformly produced severe, protracted, and eventually lethal digitalis intoxication in dogs. The electrocardiographic and gastrointestinal manifestations of digoxin intoxication were not affected by the intravenous administration of normal canine plasma or of rabbit serum containing antibodies to antigens unrelated

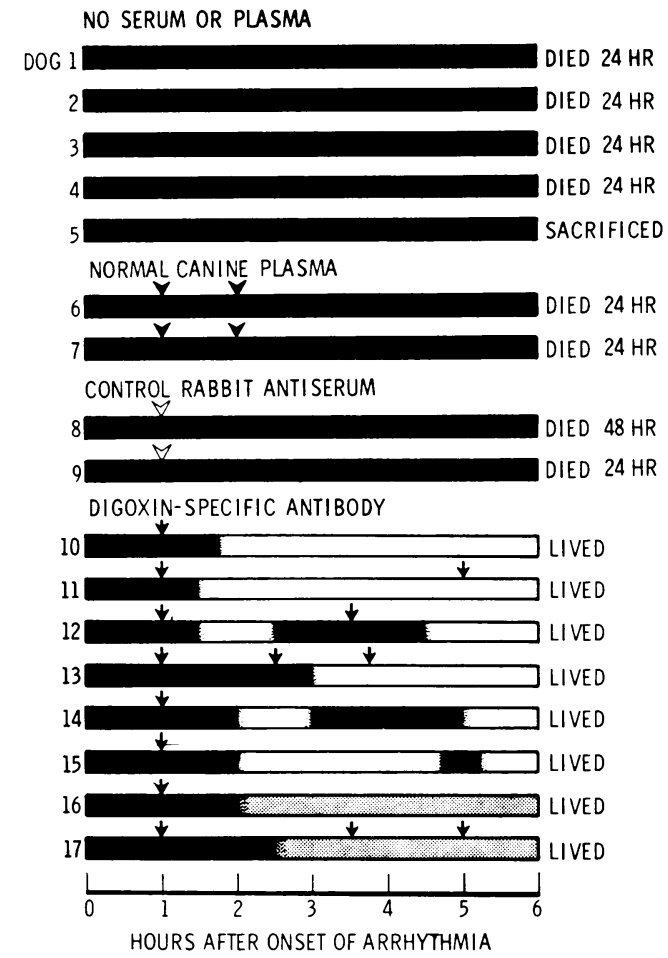

Arrhythmia Atrial tachycardia $\square$ Normal sinus rhythm

FigiRE 2 The course of digoxin-induced arrhythmias in 17 dogs. Black bars indicate the presence of one of the toxic rlythms illustrated in Fig. 1. Shaded bars denote atrial tachycardia and white bars indicate normal sinus rhythm. Normal canine plasma (closed arrowhead), control rabbit antiserum (open arrowhead), or antidigoxin antibodies (arrow) were infused at the points indicated by the symbols. The horizontal axis represents the duration of the study period in hours after the onset of arrhythmia.

to digoxin. All nine animals not treated with digoxinspecific antibodies were lead within $48 \mathrm{hr}$ of their last dose of digoxin (this number includes one moribund dog sacrificed $24 \mathrm{hr}$ after the last dose of this (lrug).

In contrast, six of the eight dogs given digoxinspecific antibodies were in normal sinus rhythm at the end of $6 \mathrm{hr}$, and all eight were free of gastrointestinal and other clinical manifestations of digitalis intoxication at that time. All eight animals, moreover. were alive and in normal sinus rhythm at the end of $72 \mathrm{hr}$. It can be concluded therefore that digoxin-specific antibodies can abolish toxic arrhythmias, reverse clinical evidence of toxicity. and prevent death in dogs given a toxic dose of digoxin.

The mechanism by which antidigoxin antibodies reverse the toxic cellular effects of excessive myocardial digoxin has not been established in the current study: We believe. on the basis of earlier studies showing removal of digoxin from kidney cells and erythrocytes in vitro (5), that this reversal may occur as the result 
of a diminished myocardial concentration of digoxin, but direct evidence for this mechanism has not yet been obtained with myocardial cells. An alternative, but less likely, explanation is that antibody binds digoxin at a cell membrane or intracellular (14) site, thereby inactivating the glycoside. Hypokalemia (15) and hypomagnesemia 16) are known to predispose to the development of digitalis toxicity. Hence, consideration was given to the possibility that the reversal of toxicity might be due to correction of potassium or magnesium deficiency by antidigoxin serum or plasma. However, in five digoxin-intoxicated dogs, serum potassium and magnesium concentrations were within normal limits. Moreover, the concentrations of potassium in serum or plasma containing antidigoxin antibodies were normal or low in all instances and did not differ significantly from their concentrations in control serum or plasma administered to dogs 6-9 (Table II). Thus, at present, there is no evidence that correction of potassium or magnesium deficits played any significant role in the reversal of digoxin toxicity by serum or plasma containing digoxin-specific antibodies.

Although reversal of digoxin toxicity and eventual restoration of normal sinus rhythm occurred in all eight animals receiving digoxin-specific antibodies, significant differences in their responses were observed. Some of these differences in response may have been related to the relative quantities of antibody administered. For example, the transitory effect of the first antibody infusion in $\log 12$ and the lack of effect after the first

TABLE II

Sources, Potassium Concentrations, and Antibody Titers of Serum and Plasma Administered to Digoxin-Intoxicated Dogs

\begin{tabular}{|c|c|c|c|c|c|c|c|}
\hline $\begin{array}{l}\text { Recipient } \\
\text { dog No. }\end{array}$ & Donor, species and number & Nature of serum or plasma & $\begin{array}{l}\text { Volume } \\
\text { adminis- } \\
\text { tered }\end{array}$ & $\begin{array}{l}\text { Potassium } \\
\text { concen- } \\
\text { tration }\end{array}$ & $\begin{array}{l}\text { Hemagglu- } \\
\text { tination } \\
\text { titer* }\end{array}$ & $\begin{array}{l}\text { Digoxin- } \\
\text { binding } \\
\text { antibody } \\
\text { titer }+\end{array}$ & $\begin{array}{l}\text { Estimated } \\
\text { digoxin- } \\
\text { binding } \\
\text { capacity } \\
\text { of volume } \\
\text { administered§ }\end{array}$ \\
\hline 6 & Dog 34 & Normal plasma & $\begin{array}{r}m l \\
130 \\
130\end{array}$ & $\begin{array}{c}m E q / \text { liter } \\
3.1 \\
3.1\end{array}$ & $\begin{array}{l}\text { ND } \\
\text { ND }\end{array}$ & $\begin{array}{l}0 \\
0\end{array}$ & $\begin{array}{l}0^{m g} \\
0\end{array}$ \\
\hline 7 & Dog 34 & Normal plasma & $\begin{array}{l}130 \\
130\end{array}$ & $\begin{array}{l}3.1 \\
3.1\end{array}$ & $\begin{array}{l}\text { ND } \\
\text { ND }\end{array}$ & $\begin{array}{l}0 \\
0\end{array}$ & $\begin{array}{l}0 \\
0\end{array}$ \\
\hline 8 & Rabbit TCP-8,9,10(Pool) & Anti-Pur-HSA serum & 400 & 4.9 & $1: 51,200$ & 0 & 0 \\
\hline 9 & Rabbit HGG-2 & Anti-HGG serum & 400 & 5.1 & $1: 25,600$ & 0 & 0 \\
\hline 10 & $\operatorname{Dog} 203_{4}$ & Anti-HSA-Dig plasma & 130 & 3.4 & $1: 400$ & $1: 150$ & 0.30 \\
\hline 11 & $\begin{array}{l}\text { Rabbit DB-11 } \\
\text { Rabbit DB-2,11(Pool) }\end{array}$ & $\begin{array}{l}\text { Anti-BSA-Dig serum } \\
\text { Anti-BSA-Dig serum }\end{array}$ & $\begin{array}{l}50 \\
25\end{array}$ & $\begin{array}{l}4.5 \\
5.5\end{array}$ & $\begin{array}{l}1: 6400 \\
1: 6400\end{array}$ & $\begin{array}{l}1: 150 \\
1: 500\end{array}$ & $\begin{array}{l}0.12 \\
0.20\end{array}$ \\
\hline 12 & $\begin{array}{l}\text { Dog } 205_{3} \\
\text { Rabbit DB-3 }\end{array}$ & $\begin{array}{l}\text { Anti-HSA-Dig plasma } \\
\text { Anti-BSA-Dig serum }\end{array}$ & $\begin{array}{r}130 \\
55\end{array}$ & $\begin{array}{l}3.8 \\
6.0\end{array}$ & $\begin{array}{l}1: 800 \\
1: 13,800\end{array}$ & $\begin{array}{l}1: 50 \\
1: 400\end{array}$ & $\begin{array}{l}0.10 \\
0.70\end{array}$ \\
\hline 13 & $\begin{array}{l}\text { Dog } 203_{5} \\
\text { Rabbit DB-2,3,11 (Pool) } \\
\text { Rabbit DB-2,3,11 (Pool) }\end{array}$ & $\begin{array}{l}\text { Anti-HSA-Dig plasma } \\
\text { Anti-BSA-Dig serum } \\
\text { Anti-BSA-Dig serum }\end{array}$ & $\begin{array}{l}130 \\
100 \\
100\end{array}$ & $\begin{array}{l}3.3 \\
6.4 \\
6.4\end{array}$ & $\begin{array}{l}1: 200 \\
1: 12,800 \\
1: 12,800\end{array}$ & $\begin{array}{l}1: 50 \\
1: 400 \\
1: 400\end{array}$ & $\begin{array}{l}0.10 \\
0.62 \\
0.62\end{array}$ \\
\hline 14 & $\operatorname{Dog} 206_{5}$ & Anti-HSA-Dig plasma & 300 & 2.5 & $1: 1600$ & $1: 300$ & 1.44 \\
\hline 15 & Dog $206_{6}$ & Anti-HSA-Dig plasma & 300 & 2.7 & $1: 400$ & $1: 100$ & 0.48 \\
\hline 16 & $\operatorname{Dog} 206_{5}$ & Anti-HSA-Dig plasma & 250 & 2.5 & $1: 1600$ & $1: 300$ & 1.20 \\
\hline 17 & $\begin{array}{l}\text { Dog } 206_{3} \\
\text { Dog } 201_{4} \\
\text { Rabbit DB-4 }\end{array}$ & $\begin{array}{l}\text { Anti-HSA-Dig plasma } \\
\text { Anti-HSA-Dig plasma } \\
\text { Anti-BSA-Dig serum }\end{array}$ & $\begin{array}{r}130 \\
130 \\
50\end{array}$ & $\begin{array}{l}3.3 \\
2.9 \\
\mathrm{ND}\end{array}$ & $\begin{array}{l}1: 1600 \\
1: 20 \\
\text { ND }\end{array}$ & $\begin{array}{l}1: 100 \\
1: 25 \\
\text { ND }\end{array}$ & $\begin{array}{l}0.20 \\
0.05 \\
\text { ND }\end{array}$ \\
\hline
\end{tabular}

ND, not done.

* Hemagglutination titer determined in each instance with cells coated with immunizing antigen; see Methods for definition of titer.

$\ddagger$ See Methods for definition of titer.

$\S$ Calculated from digoxin-binding antibody titer, see Methods. 


\begin{tabular}{|c|c|c|c|c|c|c|c|c|}
\hline \multirow[b]{2}{*}{$\begin{array}{l}\text { Dog } \\
\text { No. }\end{array}$} & \multirow[b]{2}{*}{ Infusion } & \multirow[b]{2}{*}{$\begin{array}{l}\text { Estimated } \\
\% \text { of final } \\
\text { digoxin } \\
\text { dose bound }\end{array}$} & \multirow[b]{2}{*}{$\begin{array}{l}\text { Rhythm } \\
\text { before } \\
\text { final } \\
\text { digoxin } \\
\text { dose }\end{array}$} & \multirow[b]{2}{*}{$\begin{array}{l}\text { Rhythm* at start of } \\
6 \mathrm{hr} \text { study period }\end{array}$} & \multicolumn{4}{|c|}{ Effect of antibodies on rhythm } \\
\hline & & & & & New rhythm & $\begin{array}{l}\text { Time re- } \\
\text { quired } \\
\text { for estab- } \\
\text { lishment } \\
\text { of new } \\
\text { rhythm }\end{array}$ & $\begin{array}{l}\text { Duration } \\
\text { of effect }\end{array}$ & $\begin{array}{l}\text { Time re- } \\
\text { quired } \\
\text { for perma- } \\
\text { nent estab- } \\
\text { lishment } \\
\text { of NSR }\end{array}$ \\
\hline 10 & Anti-HSA-Dig plasma & 27 & NSR & $\begin{array}{l}\text { AV dissociation with } \\
\text { junctional rhythm }\end{array}$ & NSR & $\min _{50}$ & Permanent $\ddagger$ & $50 \mathrm{~min}$ \\
\hline \multirow[t]{2}{*}{11} & Anti-BSA-Dig serum & 20 & NSR & VPC's & $\begin{array}{l}\text { NSR (prolonged } \\
\text { PR) }\end{array}$ & 15 & Permanent & $15 \mathrm{~min}$ \\
\hline & Anti-BSA-Dig serum & 33 & & & No further effect & - & - & \\
\hline 12 & $\begin{array}{l}\text { Anti-HSA-Dig plasma } \\
\text { Anti-BSA-Dig serum }\end{array}$ & $\begin{array}{l}11 \\
78\end{array}$ & NSR & 3:1 AV block & $\begin{array}{l}\text { NSR } \\
\text { NSR }\end{array}$ & $\begin{array}{l}30 \\
75\end{array}$ & $\begin{array}{c}1 \mathrm{hr} \S \\
\text { Permanent }\end{array}$ & $4 \mathrm{hr}$ \\
\hline 13 & $\begin{array}{l}\text { Anti-HSA-Dig plasma } \\
\text { Anti-BSA-Dig serum }\end{array}$ & $\begin{array}{r}8 \\
>100\end{array}$ & NSR & Ventricular tachycardia & $\begin{array}{l}\text { No effect } \\
\text { NSR }\end{array}$ & $\overline{50}$ & Permanent & $3 \mathrm{hr}$ \\
\hline 14 & Anti-HSA-Dig plasma & $>100$ & NSR & $\begin{array}{l}\text { Complete heart block } \\
\text { with idioventricular } \\
\text { rhythm }\end{array}$ & NSR & 40 & Transitory\|l & $4 \frac{1}{2} \mathrm{hr}$ \\
\hline 15 & Anti-HSA-Dig plasma & 55 & NSR & $\begin{array}{l}2: 1 \mathrm{AV} \text { block and ven- } \\
\text { tricular tachycardia }\end{array}$ & NSR & 90 & Transitoryll & $5 \frac{1}{h r}$ \\
\hline 16 & Anti-HSA-Dig plasma & $>100$ & NSR & $\begin{array}{l}\text { Idioventricular rhythm; } \\
\text { no atrial activity }\end{array}$ & Atrial tachycardia & 60 & Permanent & $72 \mathrm{hr}$ \\
\hline 17 & $\begin{array}{l}\text { Anti-HSA-Dig plasma } \\
\text { Anti-HSA-Dig plasma } \\
\text { Anti-BSA-Dig serum }\end{array}$ & $\begin{array}{r}25 \\
\text { ND }\end{array}$ & NSR & Ventricular tachycardia & $\begin{array}{l}\text { Atrial tachycardia } \\
\text { No further effect } \\
\text { No further effect }\end{array}$ & $\frac{90}{-}$ & $\begin{array}{c}\text { Permanent } \\
- \\
-\end{array}$ & $48 \mathrm{hr}$ \\
\hline
\end{tabular}

VPC's, frequent ventricular premature contractions with occasional short periods of ventricular tachycardia; NSR, normal sinus rhythm; AV, atrio ventricular; ND, not done.

* Refers to predominant arrhythmia.

$\ddagger$ Persisting until the end of $6 \mathrm{hr}$ study period.

$\$$ Reverted to AV block with brief periods of ventricular tachycardia.

\| Transitory period or original arrhythmia occurred at times indicated in Fig. 1.

antibody infusion in dog 13 are probably related to the relatively low digoxin-binding capacities of the canine antidigoxin plasma employed. In both instances, the subsequent administration of more potent rabbit antidigoxin serum was followed by a restoration of normal sinus rhythm (Table III). However, not all of the observed differences in response can be ascribed to differences in the amount of antibody administered. For example, dog 10 reverted permanently to normal sinus rhythm after receiving enough antibody to bind $27 \%$ of the final dose of digoxin, but the initial response in dogs 14 and 15 , both of which received more antibody, was transitory (Fig. 2, Table III). Dogs 16 and 17 received large quantities of antibody with rather prompt conversion of ventricular arrhythmias (idioventricular rhythm with absence of atrial activity in dog 16; ventricular tachycardia in dog 17) to atrial tachycardias with variable atrioventricular block and a slow ventricular response (Fig. 2, Table III); however, 2-3 days were required for the restoration of normal sinus rhythm in these instances.
The basis for these differences in electrocardiographic response to antidigoxin antibodies is not known at this time. The dogs employed in this study did differ markedly in their electrocardiographic response to the same toxic dosage of digoxin (Table I, III). It is well known that many factors alter host tolerance for digitalis (17). Hence, it is possible that the subsequent variability in electrocardiographic response to antidigoxin antibodies may reflect, at least in part, previously established differences in the nature of the toxic myocardial effects of digoxin in different individual animals. It is also possible that the differences in electrocardiographic response to antidigoxin antibodies may be due, at least in part, to differences in the affinities of these antibodies for digoxin. Differences in average intrinsic association constants, as much as 14 -fold $(17 \times$ $10^{\circ}$ vs. $1.2 \times 10^{\circ}$ ) have been reported between the antidigoxin antibodies of two different antisera (7); antibodies with relatively low association constants may be less effective than high-affinity antibodies in competing with myocardial digoxin-binding sites (18). 
TABLE IV

Effects of Digoxin Intoxication in Control Dogs and Dogs Receiving Digoxin-Specific Antibodies

\begin{tabular}{|c|c|c|c|c|c|}
\hline & \multirow[b]{2}{*}{ Number } & \multirow{2}{*}{$\begin{array}{l}\text { Normal } \\
\text { sinus } \\
\text { rhythm } \\
\text { at } 6 \mathrm{hr}\end{array}$} & \multicolumn{3}{|c|}{ Number alive at: } \\
\hline & & & $24 \mathrm{hr}$ & $48 \mathrm{hr}$ & $72 \mathrm{hr}$ \\
\hline \multicolumn{6}{|l|}{ Control animals } \\
\hline No serum or plasma & 5 & 0 & 0 & 一 & - \\
\hline Normal plasma & 2 & 0 & 0 & - & - \\
\hline $\begin{array}{l}\text { Antisera to antigens } \\
\text { unrelated to digoxin }\end{array}$ & 2 & 0 & 1 & 0 & - \\
\hline $\begin{array}{l}\text { Animals given digoxin- } \\
\text { specific antibodies }\end{array}$ & 8 & 6 & 8 & 8 & 8 \\
\hline
\end{tabular}

It has long been known that antibodies to certain toxic substances, such as diphtheria toxin or tetanus toxin, are incapable of reversing the toxic effects of the corresponding antigens after these toxic substances have reached their cellular sites of action (19). Recently, however, Pastan and his colleagues have shown that antibodies specific for insulin and thyrotrophin, respectively, are capable of reversing established cellular effects of these peptide hormones on certain target tissues (20). Moreover, Watson and Butler have demonstrated that digoxin-specific antibodies are capable of reversing an effect of digoxin on cation transport in human erythrocytes (5). To our knowledge, however, the current study represents the first direct demonstration that antibodies are capable of reversing a toxic cellular effect of a physiologically active substance in the intact living animal. This observation suggests that antibodies may also be of value in reversing the cellular effects of other physiologically active substances.

Finally, the ability of digoxin-specific antibodies to reverse severe, potentially lethal, digoxen intoxication in the dog suggests that these antibodies may eventually be of use in severe, life-threatening digoxin intoxication in man.

\section{ACKNOWLEDGMENTS}

We are indebted to Bette M. Kaufman, Toni H. Greene, and Patricia L. Fleming for excellent technical assistance.

This investigation was supported by U. S. Public Health Service research grants (HE-10608, AM-07183, HE-02001, HIE-05741) and by grants-in-aid from the American Heart Association (69-824) and the New York Heart Association.

\section{REFERENCES}

1. Schmidt, D. H., and V. P. Butler, Jr. 1969. Reversal of digoxin toxicity with specific antibodies. J. Clin. Invest. 48 : 74a. (Abstr.)
2. Fisch, C., and S. B. Knoebel. 1970. Recognition and therapy of digitalis toxicity. Progr. Cardiovasc. Dis. 13: 71.

3. Butler, V. P. Jr., and J. P. Chen. 1967. Digoxin-specific antibodies. Proc. Nat. Acad. Sci. U. S. A. 57: 71

4. Schmidt, D. H., and V. P. Butler, Jr. 1971. Immunological protection against digoxin toxicity. J. Clin. Invest. 50: 866 .

5. Watson, J. F., and V. P. Butler. 1968. Biologic activity of digoxin-specific antisera. Clin. Res. 16: 252. (Abstr.)

6. Erlanger, B. F., and S. M. Beiser. 1964. Antibodies specific for ribonucleosides and ribonucleotides and their reaction with DNA. Proc. Nat. Acad. Sci. U.S.A. 52: 68.

7. Smith, T. W., V. P. Butler, Jr., and E. Haber. 1970. Characterization of antibodies of high affinity and specificity for the digitalis glycoside digoxin. Biochemistry. 9: 331 .

8. Butler, V. P. Jr., S. M. Beiser, B. F. Erlanger, S. W. Tanenbaum, S. Cohen, and A. Bendich. 1962. Purinespecific antibodies which react with deoxyribonucleic acid (DNA). Proc. Nat. Acad. Sci. U. S. A. 48: 1597.

9. Herbert, V., K. S. Lau, C. W. Gottlieb, and S. J. Bleicher. 1965. Coated charcoal immunoassay of insulin. J. Clin. Endocrinol. Metab. 25: 1375.

10. Smith, T. W., V. P. Butler, Jr., and E. Haber. 1969. Determination of therapeutic and toxic serum digoxin concentrations by radioimmunoassay. $N$. Engl. J. Med. 281: 1212 .

11. Butler, V. P. Jr., and J. H. Vaughan. 1964. Hemagglutination by rheumatoid factor of cells coated with animal gamma globulins. Proc. Soc. Exp. Biol. Med. 116: 585.

12. Martin, F. N. Jr. 1946. Distribution of potassium and sodium in body. Neze Orleans Med. Surg. J. 99: 103.

13. Bernstein, R. E. 1954. Potassium and sodium balance in mammalian red cells. Science (Washington). 120: 459.

14. Ng, C. W., and K. F. Gregory. 1968. Antibody to lactate dehydrogenase. III. Uptake, accumulation and specific intracellular action in malignant cells. Biochim. Biophys. Acta. 170: 45.

15. Winsor, T. 1960. Potassium and digitalis intoxication. Amer. Heart J. 60: 151.

16. Seller, R. H., J. Cangiano, K. E. Kim, S. Mendelssohn, A. N. Brest, and C. Swartz. 1970. Digitalis toxicity and hypomagnesemia. Amer. Heart J. 79: 57.

17. Surawicz, B., and S. Mortelmans. 1969. Factors affecting individual tolerance to digitalis. In Digitalis. C. Fisch and B. Surawicz, editors. Grune \& Stratton, Inc., New York. 127.

18. Matsui, H., and A. Schwartz. 1968. Mechanism of cardiac glycoside inhibition of the $\left(\mathrm{Na}^{+}-\mathrm{K}^{+}\right)$-dependent ATPase from cardiac tissue. Biochim. Biophys. Acta. $151: 655$.

19. Cinader, B., and I. H. Lepow. 1967. The neutralization of biologically active molecules. In Antibodies to Biologically Active Molecules. B. Cinader, editor. Pergamon Press, Inc., New York. 1.

20. Pastan, I., J. Roth, and V. Macchia. 1966. Binding of hormone to tissue: the first step in polypeptide action. Proc. Nat. Acad. Sci. U. S. A. 56: 1802. 